\title{
A SYSTEMATIC REVIEW OF THE SOCIO-ETHICAL ASPECTS OF MASSIVE ONLINE OPEN COURSES
}

\author{
Vivien Rolfe [vivien.rolfe@gmail.com], University of the West of England, United Kingdom
}

\section{English Abstract}

Massive open online courses (MOOCs) offer learners across the globe unprecedented access to education. Through sophisticated e-learning technologies and web approaches, MOOCs attract massive scale participation and global interest. Some commercial ventures place social equality at the heart of their missions, claiming to empower communities by making education accessible and affordable. In reality, the socio-ethical impact of MOOCs has not been investigated fully, so it is not clear whether they meet these aspirations.

The aim of this study was to conduct a systematic literature review to examine the socio-ethical dimensions of MOOCs. The results showed a paucity of literature specifically addressing the subject in question, although there was evidence of many innovative approaches underway to examine new paradigms within learning analytics and online study behaviour that are emerging because of MOOCs. A small number of papers explored new pedagogic approaches such as conducting peer assessment on a massive scale, and how learning groups connect and establish on the open web.

To conclude, this paper begins to provide a framework on which to consider the socio-ethical dimensions of MOOCs. There is a need for good quality research to provide an evidence-base to ensure MOOCs deliver a socially equitable learning experience.

\section{French Abstract}

Les MOOC (cours en ligne ouverts à tous) offrent aux étudiants á travers le monde un accès sans précédent á l'enseignement. Grâce à des technologies d'apprentissage en ligne et des approches Web sophistiquées, les MOOC suscitent une participation à très grande échelle et un intérêt mondial. Quelques entreprises commerciales placent l'égalité sociale au cœur de leurs objectifs, affirmant émanciper les communautés en rendant l'enseignement accessible et abordable. En réalité, aucune recherche n'a été menée en profondeur pour mesurer l'impact socio-éthique des MOOCs; en conséquence, il n'est pas sûr qu'ils remplissent les objectifs visés.

Le but de cette étude était de réaliser un état de l'art de l'analyse des dimensions socio-éthiques des MOOC. Les résultats montrent un manque de publications traitant spécifiquement de ce sujet, bien que beaucoup d'approches innovantes aient été développées pour explorer de nouveaux paradigmes dans le cadre de l'analyse des processus d'apprentissage et du comportement en ligne des apprenants. Nous n'avons trouvé qu'un petit nombre d'articles explorant de nouvelles approches pédagogiques telles que l'évaluation par les pairs à grande échelle, ou étudiant comment les groupes d'apprenants entrent en contact et se forment via le web.

En conclusion, cet article commence à établir un cadre pour l'étude des dimensions socioéthiques des MOOCs. Il est nécessaire de mener des recherches de qualité pour établir la preuve que les MOOCs apportent une expérience d'apprentissage socialement équitable. 
Keywords: MOOC, massive online open course, ethics, social responsibility, inclusivity and diversity.

\section{Introduction}

The concept of an ethically sound education is grounded in ethical theories where the 'matter' of education - the curriculum and content - and also the 'manner' in which teaching is delivered, are important considerations (Peters, 1971). Peters is referring to traditional campus-based education, and these ethical values underpin modern-day academia. Marshall (2014) expands on these views in relation to massive online open courses (MOOCs), and talks about the academic duty of care and the 'manner' in which new educational forms are being delivered. With technological advances and social media expansion, there are serious ethical implications for students, and the author questions whether the duty of care is being breached at present? Thus, ethical discussions are equally relevant in modern-day education contexts (Marshall, 2014).

Delivering an ethically sound education is the central doctrine of many organisations. The United Nations Educational, Scientific and Cultural Organization 'World Declaration on Higher Education for the 21st Century' presents the equality of access to education as an underlying theme (United Nations Educational, Scientific and Cultural Organization [UNESCO], 1998), and the need for social equality penetrates many government education policies in which they strive to deliver "improved social mobility through fairer access" (Department for Business Innovation and Skills, 2011), and make studying "more accessible, affordable, and attainable" (The White House, 2014). These aspirations seem at odds with parts of the higher education sector presenting a more commercial façade (Dima, Vasilache, Ghinea \& Agoston, 2013), and universities increasingly brushing shoulders with private providers. MOOCs are no exception with offerings from academia competing with heavily-invested commercial ventures. Thus, at the heart of the present exploration of the socio-ethical dimensions of MOOCs is a sector undergoing dramatic change and with disruption to the core ideologies on which much of education was founded (Molesworth, Nixon \& Scullion, 2009).

The term MOOC was first used around 2008 and described an online course with free registration to users, and that featured a publically shared curriculum with open-ended learning outcomes (Cormier, 2008; McAulay, Stewart, Siemens \& Cormier, 2010). These first MOOCs challenged the relationships at the very heart of education, and the academics involved cooperated in shared tasks and co-creation of materials with the online learners. These early courses gave rise to new pedagogic approaches with autonomous learners working with facilitators in networked learning spaces, and were termed 'connectivist' MOOCs. In 2009, MOOCs appeared in a more structured form, with video content and assessments time-released via a hosting platform that served as the main learning arena. Today, in common parlance, MOOCs are described as cMOOCs (open on the web, connectivist paradigm) or xMOOCs (large-scale, learning platform), although in reality this terminology is becoming blurred with the level of openness, technological approaches or teacher/learner relationships no longer being clear defining characteristics of either (Conole, 2013). It is generally held that they do vary in ethos with xMOOCs "open as in door" versus cMOOCs that are "open as in heart" (Kernohan, 2012). For the purposes of this paper they will be referred to as cMOOC and $\mathrm{xMOOC}$ since that his how they are predominantly reflected to in the literature.

Through sophisticated e-learning technologies and new pedagogic approaches, MOOCs have the potential to foster equality as they undisputedly reach global audiences (Jordan, 2014). Indeed, many of the commercial ventures place social equality at their central doctrine, but are they delivering their promises? Some authors suggest that MOOCs tend to be exclusive to learners (Liyanagunawardena, Adams, Rassool \& Williams, 2013a), and it is acknowledged that the 
majority of participants 'drop-out' of courses (Jordan, 2014). These values are difficult to translate on-line even when learners are enrolled in an institution (Brey, 2006), so the challenges faced by open courses and MOOCs are immense, particularly considering the geographic, cultural and social diversity of users. Therefore it is important to define these ethical dimensions in relation to MOOCs, to provide a framework for further development.

The aim of this research was to explore socio-ethical dimensions of MOOCs. A systematic literature review was carried out to summarise current understanding, not just in terms of the opportunities MOOCs have afforded for equality and inclusivity, but also the difficulties faced. An interim report of the literature up to October 2013 was presented previously (Rolfe, 2013). For the present study, the searches were updated to October 2014 and provided an added perspective of the growing trends within the body of publications.

\section{Methodology}

\section{Systematic Review Process}

The research methodology used a systematic approach to searching and evaluating the literature. Systematic reviews are a useful tool in education research and the approach often requires the broadening of entry gate for study selection beyond what might be considered in a review of medical literature (Bearman et al., 2012). In education, the studies might be of a less robust design in a trade off between experimentation and the impracticalities of the classroom (Evans \& Benefield, 2001). In the present review, therefore, no studies were excluded on the basis of their design.

\section{Search Strategy and Timings}

The interim report covered literature up October 2013 (Rolfe, 2013), and the present paper brings the search up to date to October 2014. Journal articles were located from four electronic databases and no restrictions were placed on language or date: Web of Knowledge (Thompson Reuters); PubMed (United States National Library of Medicine); IEEE Xplore (ieee.org) and Scopus (scopus.com). To retrieve further articles, Google Scholar was used. Additional articles were retrieved from database links to "similar articles". Journals and conference proceedings were also separately searched: Journal of Online Learning and Teaching, The International Review of Research in Open and Distance Learning and the European Journal of Open, Distance and eLearning. 'OER' conferences (up to OER14) and the 'Annual Open Education Conference' (OpenEd up to 2013).

\section{Keywords and Phrases}

Lists of keywords grew iteratively with new words added from early articles retrieved. The keywords included MOOC*, cMOOX*, xMOOC*, "massiv* online open course*", "massiv* open online course*", "free online learning", and included MOOC providers and courses e.g. Coursera, MITx, edX, CCK, PLENK etc. A second group of keywords included "student experience"; social*; ethic*; inclusiv*; divers*; accessibil*; value*; quality; pedagogy, literacy.

Online databases were searched using Boolean logic, and searches were saved for future repetition. It was necessary to exclude key words and phases from the search that represented other abbreviations of MOOC, namely molybdenum (MoOCl) and "Minnie the Moocher". Google Scholar was searched just using simple keywords e.g. MOOC +ethics. 


\section{Inclusion and Exclusion Criteria for Studies}

Retrieved articles underwent two phases of sorting. Firstly the titles and abstracts of articles were reviewed for relevance and any duplicates were removed. In a second phase the full article was reviewed in accordance with the criteria set, and this was aided by using the "search in document" function to locate keywords in passages of text.

Articles were included if they evaluated a MOOC or open course made available on the internet. MOOCs could be used in any pedagogic scenario, for example used by informal learners or used as part of blended offerings for students enrolled at a university. All empirical studies were included regardless of design. Articles were excluded if they were duplicate studies, or if they presented a case study of a MOOC. Articles where the keywords were inherent but in a different context from the question were also removed, e.g. of the word "social" was identified within the paper this might simply have been in relation to a MOOC in "social sciences".

For the purpose of this study, review articles and authoritative reports were also kept within the search so to provide an indication on the trends within the literature. The results of the searches were logged into Microsoft Excel spread sheet, detailing citation details, URL, type of article, and the main research findings. For empirical studies, the method detail, study size and design, type of MOOC, and major findings were recorded.

\section{Results}

The searches identified 141 articles up to October 2013 with a further 76 articles by October 2014. Figure 1 shows the articles retrieved and items excluded at each phase; phase 1 largely excluded duplicate articles, and phase 2 was a more in depth analysis of the article relevance. 


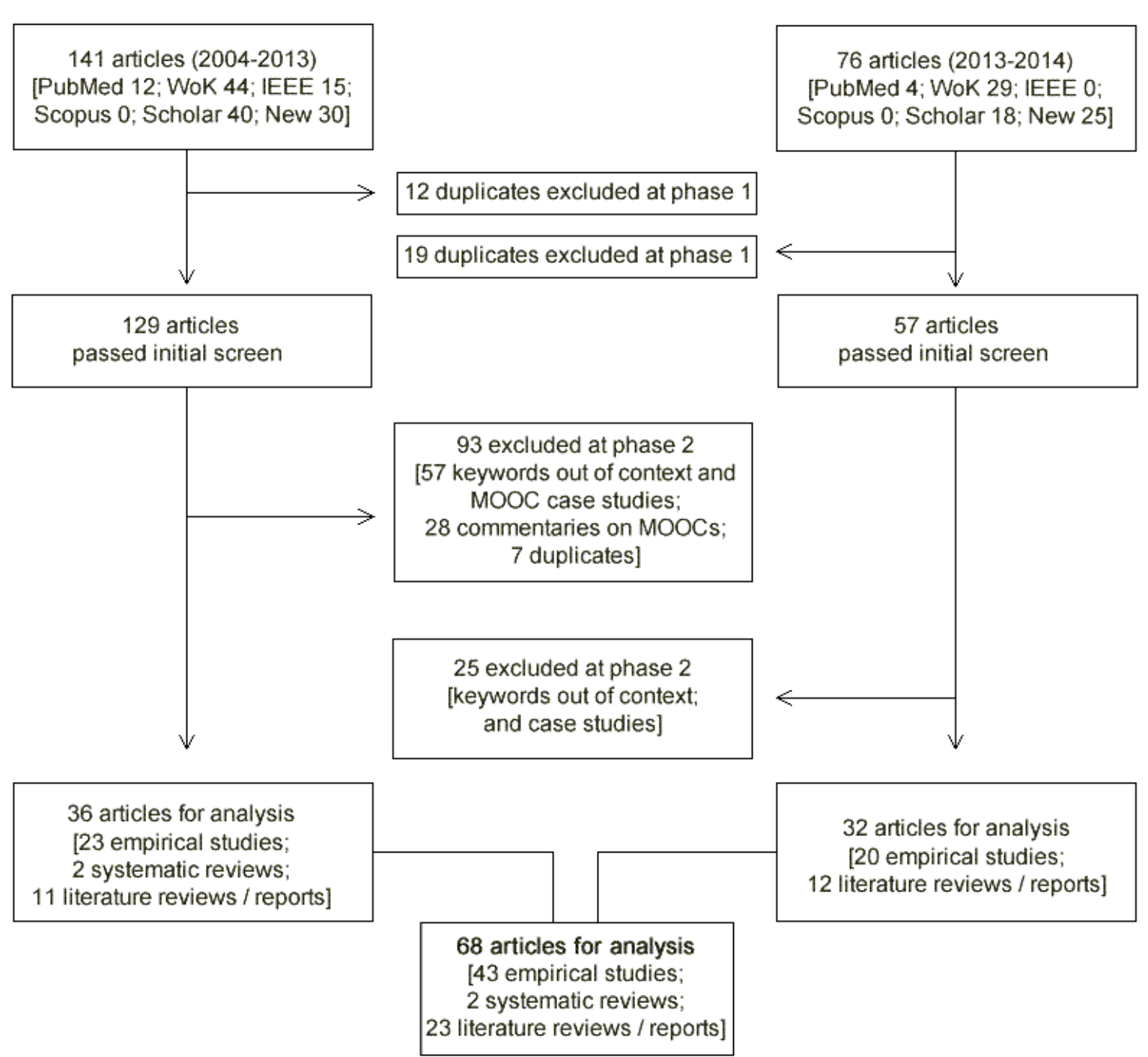

Figure 1. A flow diagram illustrating the retrieval and exclusion of articles from electronic databases PubMed, WoK (Web of Knowledge), IEEE (IEEE Explore), Scopus, Scholar (Google Scholar) and New ("similar articles" or "related document" tabs).

The combined results of both searches produced 68 articles for analysis after removing a small number of duplicates common to both. Articles included 43 empirical studies, 2 systematic reviews and 23 literature reviews or authoritative reports. The spread of publications identified by this search by time is shown in Table 1 . 
Table 1: The number of studies identified according to the type of article and year of publication.

\begin{tabular}{|l|c|c|c|c|}
\hline Author Identifier & Empirical Study & Review/report & Systematic Review & Total No. \\
\hline 2006 & 1 & 1 & & 2 \\
\hline 2009 & 3 & & & 3 \\
\hline 2010 & 4 & & 1 & 5 \\
\hline 2011 & 4 & & & 4 \\
\hline 2012 & 18 & & 1 & 18 \\
\hline 2013 & 13 & 13 & & 27 \\
\hline 2014 (to Oct.) & & 9 & $\mathbf{2}$ & $\mathbf{6 8}$ \\
\hline Total No. & $\mathbf{4 3}$ & $\mathbf{2 3}$ & & \\
\hline
\end{tabular}

\section{Types of Study and MOOC}

Two systematic reviews were identified including a review of the MOOC literature up to 2012 (Liyanagunawardena, Adams \& Williams, 2013b), and the other being a thorough examination of effective pedagogic designs for online learning (Means, Toyama, Murphy, Bakia \& Jones, 2010). Other review articles identified included peer-reviewed publications, authoritative reports and referenced editorial articles.

The analysis revealed that the empirical studies were conducted on a number of ' $c$ ' and ' $x$ ' MOOCs, and on a range of subjects. Six articles carried out a comparative analysis across two or more groups or interventions (Li et al., 2014; Kop \& Carroll, 2012; Stewart, 2010; DeBoer, Stump, Seaton \& Breslow, 2013; Kulkarni et al., 2013; Root, 2014). The remainder were crosssectional studies of MOOCs that used the built-in survey and data gathering capabilities of platform-based MOOCs, or studies that used mixed methods to survey course participant and teacher views alongside the learning analytics. 
Table 2: Summary of studies identified, type of study and name of the MOOC examined. The MOOC designation reflects that stated by the publishing author.

\begin{tabular}{|c|c|c|}
\hline Study Identifier & Study design & Type and name of MOOC \\
\hline Li et al., 2014 & $\begin{array}{l}\text { Comparison ( } 3 \text { different video } \\
\text { viewing conditions) }\end{array}$ & Numeracy, Signal Processing MOOC \\
\hline Kop \& Carroll, 2012 & $\begin{array}{l}\text { Comparison ( } 3 \text { groups, end } \\
\text { survey, lurker and active } \\
\text { participants) }\end{array}$ & Plenk2010 cMOOC \\
\hline Stewart, 2010 & Comparison study (2 groups) & Plenk2010 \\
\hline DeBoer et al., 2013 & $\begin{array}{l}\text { Comparison study (multiple } \\
\text { groups) }\end{array}$ & $\begin{array}{l}\text { edX } 6.002 \text { "Circuits and electronics" } \\
\text { xMOOC }\end{array}$ \\
\hline Root, 2014 & $\begin{array}{l}\text { Comparison study learning gains } \\
\text { (pre-test versus post) }\end{array}$ & Coursera, veterinary xMOOC \\
\hline Kulkarni et al., 2013 & $\begin{array}{l}\text { Comparison of peer assessment } \\
\text { effectiveness (iteration } 1 \text { versus } \\
\text { iteration 2) }\end{array}$ & $\begin{array}{l}\text { Coursera, "Human-centered interaction } \\
\text { design" xMOOC }\end{array}$ \\
\hline Rose et al., 2014 & Cross section & $\begin{array}{l}\text { Coursera, "Conversation that works" } \\
\text { xMOOCs }\end{array}$ \\
\hline European Commission, 2014 & Cross section & MOOCs in general \\
\hline Vazquez-Cano, 2013 & Cross section & Courera xMOOCs \\
\hline Gooding et al., 2013 & Cross section & John Hopkins, Public health MOOCs \\
\hline Griesbaum, 2014 & Cross section & $\begin{array}{l}\text { "Collaborative Knowledge Management" } \\
\text { xMOOC }\end{array}$ \\
\hline Khalil \& Ebner, 2013 & Cross section & MOOCs in general \\
\hline Koutropoulos et al., 2012 & Cross section & MobiMooc (Mobile cMOOC) \\
\hline Rodriguez, 2012 & Cross section & $\mathrm{xMOOCs}$ and $\mathrm{cMOOCs}$ \\
\hline Ahn et al., 2013 & Cross section & P2P Uiversity \\
\hline Gillani, 2013 & Cross section & $\begin{array}{l}\text { Coursera "Foundations of Business } \\
\text { Strategy" xMOOC }\end{array}$ \\
\hline DeBoer et al., 2014 & Cross section & MIT 6.002 "Circuits and electronics" \\
\hline Aiken et al., 2013 & Cross section & Coursera Introductory physics xMOOC \\
\hline Clow, 2013 & Cross section & $\begin{array}{l}\text { cMOOCs and xMOOCs; openED } 2.0 \\
\text { course. }\end{array}$ \\
\hline Grunewald et al., 2013 & Cross section & openHPI, xMOOC, Germany \\
\hline Levy, 2011 & Cross section & Plenk2010 cMOOC \\
\hline Milligan et al., 2013 & Cross section & Change11 cMOOC \\
\hline Beaven et al., 2014 & Cross section & OT12 language cMOOC \\
\hline $\begin{array}{l}\text { Saadatmand \& Kumpulainen, } \\
2014\end{array}$ & Cross section & cMOOCs (PLENK, CCK11, EC\&I 831) \\
\hline Paton, 2014 & Cross section & Health informatics MOOC \\
\hline Forsey et al., 2013 & Cross section & Sociology, MOOC type not defined \\
\hline Guo \& Reinecke, 2014 & Cross section & 4 edX xMOOCs \\
\hline Emanuel, 2013 & Cross section & 32 Coursera xMOOCs \\
\hline Andersen \& Ponti, 2014 & Cross section & $\mathrm{P} 2 \mathrm{PU}$ \\
\hline Mackness et al., 2013 & Cross section & $\begin{array}{l}\text { "First Steps in Learning and Teaching in } \\
\text { HE" FSLT12 cMOOC }\end{array}$ \\
\hline Mackness et al., 2010 & Cross section & CCK08, cMOOC \\
\hline Mak et al., 2010 & Cross section & CCK08 cMOOC \\
\hline Spoelstra et al., 2014 & Cross section & MOOCs and open online courses \\
\hline DeWaard et al., 2011 & Cross section & MobiMooc (Mobile cMOOC) \\
\hline $\begin{array}{l}\text { Liyanagunawardena et al., } \\
2013 c\end{array}$ & Cross section & Online learning in general \\
\hline Adams et al., 2014 & Cross section & xMOOCs in general \\
\hline Balakrishnan, 2013 & Cross section & edx Berkley edX CS169.1x \\
\hline Chen et al., 2012 & Cross section & Coursera, 5 xMOOCs analysed \\
\hline Seaton et al., 2013 & Cross section & MITx (now edX) $6.002 x$ \\
\hline Irvine et al., 2013 & Cross section & Multimodal online learning \\
\hline Fini, 2009 & Cross section & CCK08 \\
\hline Kop, 2011 & Cross section & CritLit and Plenk2010 \\
\hline Kop et al., 2011 & Cross section & CCK11 and Plenk2010 \\
\hline
\end{tabular}




\section{Main Themes of Investigation}

The analysis showed that a number of studies evaluated MOOC learner perceptions and behaviours using the in-built pre- and post- surveys that are integral to many large-scale platformbased MOOCs. In these studies the authors evaluated learner activity and preferences for platform tools by processing the learning analytics to trace digital movement throughout the course. Within this subset of studies, there were three sub-themes:

1. evolving new methodologies for presenting and modelling learner data and digital traces,

2. use of analytics to understand learner behaviour and participation, and

3. learner perceptions of MOOCs (Table 3).

Table 3: Summary of studies retrieved that used platform analytics and new data visualisation techniques to assess learner behaviour within the MOOC.

\begin{tabular}{|l|l|l|}
\hline Theme & Sub-theme & Reference identifier \\
\hline $\begin{array}{l}\text { Use of platform- } \\
\text { based learning } \\
\text { analytics }\end{array}$ & $\begin{array}{l}\text { Use of analytics to describe and/or } \\
\text { predict learner behaviour and } \\
\text { participation }\end{array}$ & $\begin{array}{l}\text { Guo \& Reinecke (2014); Andersen \& } \\
\text { Ponti (2014); Balakrishnan (2013); } \\
\text { Chen et al. (2012); Seaton et al. } \\
\text { (2013); Ahn et al. (2013) }\end{array}$ \\
\hline $\begin{array}{l}\text { Learner } \\
\text { behaviours }\end{array}$ & $\begin{array}{l}\text { Defining characteristics of active, } \\
\text { passive or lurker participants, } \\
\text { learning cultures and learner } \\
\text { motivations }\end{array}$ & $\begin{array}{l}\text { Kop\& Carroll (2012); Milligan et al. } \\
\text { (2013); Saadatmand \& Kumpulainen } \\
\text { (2014); Grunewald et al. (2013) }\end{array}$ \\
\cline { 2 - 4 } & $\begin{array}{l}\text { Attrition (dropping-out) and } \\
\text { conceptualisation of key stages of } \\
\text { participation }\end{array}$ & Clow (2013); DeBoer et al. (2014) \\
\cline { 2 - 3 } & $\begin{array}{l}\text { The nature of collaborative working, } \\
\text { use of tools and sense of identity }\end{array}$ & $\begin{array}{l}\text { Spoelstra et al. (2014); Mak et al. } \\
\text { (2010); Rose et al. (2014) }\end{array}$ \\
\cline { 2 - 4 } & $\begin{array}{l}\text { Analysis of performance in three } \\
\text { subject MOOCs }\end{array}$ & $\begin{array}{l}\text { Gooding et al. (2013) Aiken et al. } \\
\text { (2013); Paton (2014) }\end{array}$ \\
\hline $\begin{array}{l}\text { Learner } \\
\text { perceptions of } \\
\text { experience }\end{array}$ & $\begin{array}{l}\text { Learner perceptions including } \\
\text { interactions with facilitators, } \\
\text { motivations to participate and overall } \\
\text { satisfaction }\end{array}$ & $\begin{array}{l}\text { Beaven et al. (2014); Adams et al. } \\
\text { (2014); Khalil \& Ebner (2013) }\end{array}$ \\
\cline { 2 - 3 } & $\begin{array}{l}\text { Motivations to participate, use of } \\
\text { tools }\end{array}$ & Fini (2009); Griesbaum (2014) \\
\hline
\end{tabular}

A second group of studies were more closely concerned with the social and ethical dimensions of MOOCs, although in only a very few cases was this the primary research objective of the study. These studies used a combination of in-built platform learner analytics and mixed methods to harvest participant and/or facilitator views. The themes related to the 'matter' of education - that is, considerations regarding the quality of content and effective pedagogies, and also the 'manner' in which courses were delivered to diverse learner groups. 
Table 4: Summary of the main themes and sub-themes of studies exploring the socio-ethical dimensions of MOOCs

\begin{tabular}{|c|c|c|}
\hline Theme & Sub-theme & Reference identifier and description \\
\hline \multirow[t]{3}{*}{ MOOC Quality } & $\begin{array}{l}\text { Use of scientific citations within } \\
\text { MOOCs }\end{array}$ & $\begin{array}{l}\text { Negligible use of journal articles and literature } \\
\text { sources in } 67 \text { Coursera MOOCs questioning the } \\
\text { quality of some content presented (Vazquez-Cano, } \\
2013 \text { ) }\end{array}$ \\
\hline & Learning gains & $\begin{array}{l}\text { Improved learning gains from veterinary science } \\
\text { MOOC (Root, 2014) }\end{array}$ \\
\hline & Peer-review & $\begin{array}{l}\text { Enhancing the quality and effectiveness of large- } \\
\text { scale peer-assessment in MOOC (Kulkarni et al., } \\
\text { 2013) }\end{array}$ \\
\hline \multirow[t]{4}{*}{$\begin{array}{l}\text { Emerging } \\
\text { pedagogies }\end{array}$} & $\begin{array}{l}\text { Flipped classrooms using } \\
\text { MOOCs }\end{array}$ & $\begin{array}{l}\text { Enhancing classroom dynamics by using MOOCs to } \\
\text { 'flip' a sociology class (Forsey et al., 2013); increasing } \\
\text { video interactivity and collaborative group } \\
\text { conversations in a 'flipped' classroom formats (Li et al. } \\
2014 \text { ) }\end{array}$ \\
\hline & $\begin{array}{l}\text { Exploring multi-access points to } \\
\text { education }\end{array}$ & $\begin{array}{l}\text { Early report of student views on multi-modal learning } \\
\text { including MOOCs and open courses, with benefits } \\
\text { including the ease of access, flexibility and autonomy } \\
\text { of study (Irvine et al., 2013) }\end{array}$ \\
\hline & Mobile delivery of MOOCs & $\begin{array}{l}\text { Emerging preferences and characteristics of user } \\
\text { interactions in a mobile MOOC interface; the space } \\
\text { becomes self-organising and decentralizing } \\
\text { (DeWaard et al., 2011) }\end{array}$ \\
\hline & $\begin{array}{l}\text { Connectivism and networked } \\
\text { learning }\end{array}$ & $\begin{array}{l}\text { Emergent networked learning pedagogy (Kop et al., } \\
\text { 2011) }\end{array}$ \\
\hline \multirow[t]{2}{*}{$\begin{array}{l}\text { Social inclusion } \\
\text { afforded by MOOCs }\end{array}$} & Social inclusion and accessibility & $\begin{array}{l}\text { Requirements of social and technological } \\
\text { infrastructure to support open learning in rural areas } \\
\text { (Liyanagunawardena et al., 2013c) }\end{array}$ \\
\hline & Exclusivity & The exclusivity of MOOCs (Emanuel, 2013) \\
\hline $\begin{array}{l}\text { Digital and social } \\
\text { media literacies }\end{array}$ & Digital and social media literacy & $\begin{array}{l}\text { The digital / social literacy skills of MOOC participants } \\
\text { were not factors in successful engagement or } \\
\text { completion (Stewart, 2010) }\end{array}$ \\
\hline \multirow[t]{4}{*}{ Learner diversity } & $\begin{array}{l}\text { Learning analytical } \\
\text { representation of participant } \\
\text { diversity }\end{array}$ & $\begin{array}{l}\text { Geographic and demographic diversity of PLENK10 } \\
\text { learners (Levy, 2011; Kop, 2011) and Coursera } \\
\text { learners (Gillani, 2013); geographic, educational } \\
\text { diversity of edX MOOC and motivations to participate } \\
\text { (DeBoer et al., 2013); Geographic and demographic } \\
\text { diversity across a number of MOOCs (Rodriguez, } \\
\text { 2012; European Commission, 2014); Demographic } \\
\text { and geographic diversity of mobiMOOC (DeWaard et } \\
\text { al., 2011) }\end{array}$ \\
\hline & $\begin{array}{l}\text { Diversity and autonomy in } \\
\text { MOOCs }\end{array}$ & $\begin{array}{l}\text { Tensions between providing support for diverse } \\
\text { MOOC users and providing autonomy (Mackness et } \\
\text { al., 2013); openness versus traditipal learning } \\
\text { structures (Mackness et al., 2010); no predicting of } \\
\text { MOOC participation, motivation and autonomy from } \\
\text { social network interactions in a diverse group of } \\
\text { learners (Koutropoulos et al., 2012) }\end{array}$ \\
\hline & Diversity and critical literacies & $\begin{array}{l}\text { Challenges caused by diversity and diverse literacies } \\
\text { in providing an open, autonomous learning } \\
\text { experience (Kop, 2011) }\end{array}$ \\
\hline & Cultural diversity & $\begin{array}{l}\text { Challenges arising from diversity of cultures and } \\
\text { genders, and the formation of meaningful } \\
\text { collaborations between facilitator and learner (Kop et } \\
\text { al., 2011) }\end{array}$ \\
\hline
\end{tabular}




\section{Discussion}

This study explored the socio-ethical dimensions of MOOCs. Brey argues that for learning to translate from the classroom to computer-based instruction, the academic values of the host institution need to feature within the online space (Brey, 2006). Equality is a foundation stone of educational philosophy and practice (Peters, 1971), and as technological advances give rise to new forms of education, these ethical values remain equally important: "we have a professional and social obligation to ensure that we are not abusing a position of trust and responsibility and acting, irrespectively of our wider goals and intentions, in an unethical manner" (Marshall, 2014, p.2).

The present paper examined ethical values in the context of MOOCs where learners are largely remote from campus settings and entirely independent of any institutional enrolment or jurisdiction. Overall, a targeted search of the literature retrieved 43 empirical studies exploring both $\mathrm{x}$ - and cMOOC typologies, with many papers describing new approaches to visualizing learner digital traces, and providing insight into open learner behaviour. A small number of papers were concerned with the student experience, and a similar finding was presented in a previous systematic review of MOOC literature where the focus on participant satisfaction was one of only eight designated categories of publication (Liyanagunawardena et al., 2013b). The present analysis concurs with these authors that there is a gap in the literature relating to the experience of MOOC learners, not just in terms of their academic success but also from a social, cultural and ethical perspective. The studies retrieved represented a mix of $\mathrm{x}$ - and cMOOC designs on a wide range of subjects. There is no intention to unpick the design elements and pedagogies beyond this simple typography in order to relate them to the socio-ethical discussion, since many of the features such as level of openness, technologies and tools used, learner-teacher interactions, are blurred, and are not defining features of one form over the other (Conole, 2013).

The approach to framing the ethical enquiry stemmed from a previous study that used a thematic analysis of a number of review articles on MOOCs, and mapped the topics that emerged from the analysis to Khan's 'eLearning Framework'. This framework describes a number of dimensions such as diversity, legal issues and digital divide, as areas of consideration for implementing electronic learning (Morrison \& Khan, 2003). The analysis of the MOOC literature provided a reinterpretation of the framework to modern day educational contexts, and for example identified the need to consider ethical online behaviour, and digital and social media literacies (Rolfe, 2015). The studies retrieved in the systematic review were thus categorized based on the reinterpreted framework, and four ethical dimensions reflected in the literature:

- $\quad$ MOOC Pedagogy and Quality;

- Social inclusion afforded by MOOCs;

- Learner diversity and equality, and

- Digital and social media literacy of open learners.

\section{MOOC Pedagogy and Quality}

Both c- and xMOOCs are driving the emergence of innovative pedagogic approaches, and whether providing co-operative learning through connected online groups, or opportunities through learning management platforms, the challenge for educators is one of scale. MOOCs, in all their variety, can provide a broad repertoire of learning opportunities with accessible, flexible and autonomous study options to suit the participant (Irvine, Code, \& Richards, 2013), but are they enhancing the quality of education? MOOCs are suggested to enhance on-campus course delivery, and in 'flipped' classroom scenarios have been shown to improve group collaboration and dynamics within face-to-face teaching sessions (Forsey, Low \& Glance, 2013; Li et al., 2014). 
C-MOOCs delivered on mobile devices for open learners not enrolled to an institution provided flexible study options for those who were able to engage with social media to assist their learning (DeWaard et al., 2011). At the core of these activities are groups of learners forming social groups and enjoying collegiality, although it is reported that at the periphery, learners can feel 'decentralised' and less in control, and less able to gain a quality experience through the required channels (DeWaard et al., 2011). These studies are providing a useful interpretation of these new learning paradigms and are highlighting the challenges faced by facilitators in balancing learner autonomy with required levels of support (Mackness, Mak \& Williams, 2010), but are also providing sophisticated insights into how fruitful collaborations with diverse learner groups can be formed (Kop, Fournier \& Mak, 2011).

Another prevalent question is whether MOOCs truly innovate or are in danger of scaling up existing poor practices? One of the emerging characteristics of xMOOCs is the automation of teaching delivery, enabling the learner to complete tasks that may or may not lead to a certificated assessment. A recent report into open education more generally identified the need to address the quality of initiatives, and this could be achieved by linking up to existing trusted networks from formal education (Camilleri, Ehrlers \& Pawlowski, 2014). For other forms of open education, ideas to ensure quality of content included a 'gatekeeper' role for the institution, or peer-review approaches akin to academic publishing (Yuan \& Powell, 2013). Despite this debate within the open education sector, in reality, very few studies have investigated the quality of MOOCs to ascertain whether there is a problem with the content being delivered. In only one study identified in the present research was the robustness of the academic content of xMOOCs deemed questionable, in what was a review of the use of peer-reviewed sources across a sample of courses on one MOOC platform (Vazquez-Cano, 2013). We also know little about what makes for an effective pedagogic experience in MOOCs. In a systematic review of the effectiveness of online learning compared to classroom instruction, one major finding was that elements such as video and quizzes did not influence student learning in online classes, whereas instructor interaction did (Means et al., 2010). One particular area for which the quality of MOOCs has been staunchly questioned relates to the processes for authenticating work and how the security of submitting assessments openly can be assured, particularly in large-scale platformbased courses (Nyoni, 2013)? In what is an emerging field of research, one study evaluated the use of a massive-scale peer-review process for marking MOOC assessments, and learner results were validated against the marks given by academic instructors. With careful intervention, peerreview on a large scale was shown to be rigorous and successful (Kulkarni et al., 2013). In all of this debate around the academic quality and assurance mechanisms of open learning, MOOCs are being compared to traditional campus-based delivery and quality assurance processes, but we do not yet know what the relevant measures are, and what aspects of academic quality should be governed, and how?

\section{Social Inclusion Afforded by MOOCs}

The issue of social inclusivity is a question that remains to be resolved in MOOCs. X-MOOCs in particular inarguably reach massive global audiences (Jordan, 2014) so must by definition be enhancing equality as learning opportunities reach more diverse social groups than ever before. MOOCs reach geographically dispersed audiences (Levy, 2011; Kop, 2011; Gillani, 2013; DeWaard et al., 2011) although the emerging user demographic is polarised toward Englishspeaking and well educated students (DeBoer et al., 2014; Emanuel, 2013). There are added concerns that the content is also lacking in social diversity with the predominance of knowledge and technological ideologies of Western cultures providing the basis of most MOOCs, and it was argued that this might inhibit the emergence of local and authentic academic practices (Altbach, 2014). In remote geographic areas, there is often a distinct deficit of local infrastructure and technical support for those wishing to use study online, and this does little to ensure equitable 
access to learning for those in poorer or rural settings (Liyanagunawardena et al., 2013a). MOOCs are undoubtedly stretching the possibilities of educational delivery but there needs to be a targeted exploration of the open learners who lack access to these opportunities, rather than providing solutions that continue to serve those most privileged.

\section{Learner Diversity and Equality}

So if MOOCs are able to cross geographical boundaries and reach massive audiences, how do they fare in addressing issues of equality in relation to open learning and assessment? Many studies that have evaluated the experience of open learners suggest that the courses attract geographically, culturally and academically diverse audiences on a massive scale (Levy, 2011; Kop, 2011; DeBoer et al., 2013; Rodriguez, 2012). More closely studied have been the cMOOCs where new learner habits are closely observed through the regular interactions with the instructors or facilitators. Studies show that some individuals prefer to work in isolation and are deemed 'lurkers' compared to others who more actively participate (Milligan, Littlejohn \& Margaryan, 2013). Participants may vary their levels of engagement during the course (Guo \& Reinecke, 2014), so MOOCs are encouraging a diverse range of study habits and provide learner autonomy and freedom. However in terms of understanding open learners and their academic needs, notably absent from the literature was any reference to those with specific requirements. One study interviewed a dyslexic student who claimed that engaging with such unstructured content was tiring (Mackness et al., 2010). If MOOCs are to deliver their promises of inclusivity and equality, and if education providers do not wish to deviate from the academic and ethical values that are the mainstay of campus-based provision, the requirements of diverse learner groups is another area that should be more fully explored.

\section{Digital and Social Media Literacies}

Much of the MOOC debate has revolved around the large numbers who drop out of the learning experience (Jordan, 2014). Yet, despite this seemingly important question, few studies have explored phenomenon and we know little about the experiences of the learners who do withdraw. In a study of xMOOCs, time was cited as a feature for disengaging with study (Fini, 2009). It might also be rational to assume that lack of social and digital literacies may be a feature toward dropping out, but in a comparative study of two groups of differing levels of digital competency, this was not the case (Stewart, 2010). What we know from distance learning, where students are formally enrolled to an institution, is that instructor attitude and feelings of isolation are reasons for not completing study (Sun, Tsai, Finger, Chen \& Yeh, 2008; Willging \& Johnson, 2009). What we do not know is whether these measures of withdrawal are relevant to open learning on the web, and evidence tentatively suggests that participants might 'dip in and out' once they have achieved their aims within a course (Liyanagunawardena, Parslow \& Williams, 2014). Studies in xMOOCs that can readily track learner movement shows that participants are seemingly defining their own learning paths and not navigating the content and assessment tasks in a linear manner, so may be satisfied regardless of their level of completion (Guo \& Reinecke, 2014).

There may be added challenges within the cMOOC pedagogy where the literacies and motivation of participants may be even more crucial for them to engage through social media. As these new educational paradigms play-out, learners are certainly experimenting and finding ways in which to participate in their chosen digital space. There is a need for quality research to explore learner literacies, and this in itself is fraught with difficulty as those choosing to participate in the research will naturally be those more proactive and engaged in their study. For much of the work that lies ahead, researchers need to find mechanisms to reach those who 'drop out' or feel excluded from the learning experience, to really understand the levels of inequality that may be manifesting. 
One important ethical dimension identified much of the discussion relating to MOOCs but not at all highlighted in the papers retrieved by the present searches, is that relating to intellectual property rights and data privacy. It is acknowledged that the collection of personally identifiable information is a component part of most MOOCs, particularly within the commercial platforms with their built-in data-gathering features (Williams, 2013). The risk of interception and use by unrelated commercial partners, and the loss of intellectual property rights when students enroll are both identifiable issues (Marshall, 2014; Nyoni, 2013). In terms of copyright infidelity, other authors question how fraudulent practices can be avoided, and how it can be ensured that learners submitting assignments are not committing academic offenses (Hew \& Cheung, 2012). As suggested, technology has eased the acquisition of knowledge and with it has disrupted completely the mechanics of managing intellectual property: "mass intellectuality thrives on the porosity of the Internet, leaking into emerging spaces and counter flowing against capital's networks, transgressing intellectual property on an epidemic scale" (Neary \& Winn, 2009, p.207). One solution to this comes with the use of open licenses, often adopted by courses that connect open learners through communities on the web such as DS106 (http://ds106.us). Despite the high levels of attention given to these issues in academic institutions, there is a surprising lack of enquiry regarding the risks faced by open learners, or indeed even what people's perceptions of these risks might be as the line between traditional education and commercial enterprise begins to blur.

\section{Limitations}

This study identified and discussed a number of empirical research studies relating to MOOCs based on a systematic approach to retrieving and selecting studies. Systematic reviews are recognised as being an important constituent of education research in that they use a structured approach to searching and analysing literature, and provide a robust means of identifying gaps where inquiry is needed. In education it is accepted that the entry gate for article selection into the final analysis may be broad due to the impracticalities of the classroom (Evans \& Benefield, 2001). Thus, one of the limitations of this analysis is the inclusion of studies of a variety of design, those with comparator groups and those that were cross-sectional observations of open learning. None were excluded on the basis of their design or scale, so the level of interpretation and conclusions drawn is done so tentatively. In systematic reviews it is not unusual for multiple reviewers to participate at key decision-making points, particularly where data is extracted and pooled for further analysis. In this study, there was no intention from the outset to pool data therefore multiple authors were not employed,

\section{Conclusions}

The technological innovations that have given rise to MOOCs, and the new pedagogies that are emerging, are redefining educational possibilities. Anyone with an internet connection can access global higher education content and tuition. However, these developments have outpaced our critical thinking around the fundamental principles of how to deliver an education that is ethically sound? This review identified a growing body of literature that has explored the social and ethical dimensions of $\mathrm{c}$ - and xMOOCs. Many of the articles published provide empirical evidence showing that both forms of MOOC offer opportunities to learn and connect across geographical boundaries, yet we are at a point where social inclusion is polarised toward the more privileged. There are questions regarding the quality of MOOCs and how or whether quality should be assured, and by whom. MOOCs clearly can produce successful and satisfied learners, and more insight into digital literacies required, and how learners and facilitators can effectively collaborate online will push further the boundaries of inclusion. 
To conclude, this paper provides an evidence-base on which to consider the socio-ethical dimension of MOOCs and identifies as yet unexplored (or at least unpublished) areas of ethical consideration such as intellectual property ownership, data privacy and what constitutes ethical online learner and teacher behaviour? Future research also needs to attempt to target those more troublesome scenarios where learners 'drop out' or even fail to access MOOCs at all, and only then will we have a deeper insight into what makes a socially inclusive and equitable open learning experience via the internet.

\section{References}

1. Altbach, P.G. (2014). MOOCs as neocolonialism: who controls knowledge? In International Higher Education, 75(Spring), (pp. 5-7). Available online at http:// ejournals.bc.edu/ojs/index.php/ihe/article/view/5426/4854

2. Bearman, M.; Smith, C.D.; Carbone, A.; Slade, S.; Baik, C.; Hughes-Warrington, M. and Neumann, D.L. (2012). Systematic review methodology in higher education. In Higher Education Research and Development, 31(5), (pp. 625-640). doi:10.1080/07294360.2012.702735

3. Brey, P. (2006). Social and ethical dimensions of computer-mediated education. In Journal of Information, Communication and Ethics in Society, 2, (pp. 91-102). ISSN: 1477-996X

4. Camilleri, A.F.; Ehlers, U.D. and Pawlowski, J. (2014). State of the art review of quality issues related to Open Educational Resources (OER). European Commission Report. Available online at http:/ /is.jrc.ec.europa.eu/pages/EAP/documents/201405JRC88304.pdf

5. Conole, G. (2013). A new classification for MOOCs. Web log post, 2013, June 4. Available online at http://mooc.efquel.org/a-new-classification-for-moocs-grainne-conole/

6. Cormier, D. (2008). The CCK08 MOOC - Connectivism course, 1/4 way. Web log post, 2008, October 2. Available online at http://davecormier.com/edblog/2008/10/02/the-cck08mooc-connectivism-course-14-way/

7. Department for Business Innovation and Skills (2011). Higher education: Putting students at the heart of the system. Available online at https://www.gov.uk/government/news/puttingstudents-at-the-heart-of-higher-education

8. Dima, A.M.; Vasilache, S.; Ghinea, V. and Agoston, S. (2013). A model of academic social responsibility. In Transylvanian Review of Administrative Sciences, (38 E), (pp. 23-43).

9. Evans, J. and Benefield, P. (2001). Systematic reviews of education research: Does the medical model fit? In British Educational Research, 27(5), (pp. 527-541). doi: 10.1080/01411920120095717

10. Hew, K.F. and Cheung, W.S. (2012). Student participation in online discussions: Challenges, solutions, and future research. New York: Springer.

11. Jordan, K. (2014). Initial trends in enrolment and completion of massive open online courses. In The International Review of Research in Open and Distance Learning, 15(1). Available online at http://www.irrodl.org/index.php/irrodl/article/view/1651/2774

12. Kernohan, D. (2012). Open as in door or open as in heart? \#mooc. Web log post, 2012, May 14. Available online at http:// followersoftheapocalyp.se/open-as-in-door-or-open-as-in-heartmooc/

13. Liyanagunawardena, T.; Adams, A.; Rassool, N. and Williams, S. (2013a). Telecentres and elearning. In British Journal of Educational Technology, 44(5), (pp. E156-E158). ISSN 1467-8535, doi: 10.1111/bjet.12020. 
14. Liyanagunawardena, T.R.A.; Adams, A.A. and Williams, S.A. (2013b). MOOCs: A systematic study of the published literature 2008-2012. In The International Review of Research in Open and Distance Learning, 14(3), (pp. 202-227). Available online at http://www.irrodl.org/index.php/irrodl/article/view/1455/2531

15. Liyanagunawardena, T.R.; Parslow, P. and Williams, S. (2014). Dropout: MOOC participant perspective. In EMOOCs 2014, the Second MOOC European Stakeholders Summit, 10-12 February 2014, Lausanne, Switzerland. Paper Available online at http:// centaur.reading.ac.uk/36002/2/MOOC\%20Dropout \%20Participants\%20Perspective. pp95-100.pdf

16. Marshall, S. (2014). Exploring the ethical implications of MOOCs. In Distance Education, 35(2), (pp. 250-262). doi:10.1080/01587919.2014.917706

17. McAulay, A.; Stewart, B.; Siemens, G. and Cormier, D. (2010). The MOOC model for digital practice. University of Prince Edward Island. Available online at http://www.elearnspace.org/Articles/MOOC_Final.pdf

18. Means, B.; Toyama, Y.; Murphy, R.; Bakia, M. and Jones, K. (2010). Evaluation of EvidenceBased Practices in Online Learning: A Meta-Analysis and Review of Online Learning Studies. US Department of Education. Office of Planning, Evaluation, and Policy Development. Policy and Program Studies Service. ED-04-CO-0040. Available online at http://www2.ed.gov/rschstat/eval/tech/evidence-based-practices/finalreport.pdf

19. Molesworth, M.; Nixon, E. and Scullion, R. (2009). Having, being and higher education: The marketisation of the university and the transformation of the student into consumer. In Teaching in Higher Education, 14(3), (pp. 277-287).

20. Morrison, J.L. and Khan, B.H. (2003). The global e-learning framework: An interview with Badrul Khan. In The Technology Source, May/June 2003. Available online at http://technologysource.org/article/global_elearning_framework/

21. Neary, M. and Winn, J. (2009). The student as producer: reinventing the student experience in higher education. In The future of higher education: policy, pedagogy and the student experience, (pp. 192-210). Continuum, London. ISBN 1847064728.

22. Nyoni, J. (2013). The viral nature of massive open online courses (MOOCs) in open and distance learning: discourses of quality, mediation and control. In Mediterranean Journal of Social Sciences, 4(3). doi:10.5901/mjss.2013.v4n3p665.

23. Peters, R.S. (1971). Ethics and education. London: Unwin University Books.

24. Rolfe, V. (2013). MOOCs and social responsibility toward learners. In OPEN-ED Open Education Conference 2013. Utah, Park City, November 6-8, 2013.

http://vivrolfe.com/uncategorized/mooc-research-on-student-experience-and-socialresponsibility-toward-learners/

25. Rolfe, V. (2015). Ethical dimensions of massive open online courses. Manuscript submitted for publication.

26. United Nations Educational, Scientific and Cultural Organization [UNESCO] (1998). Higher education in the twenty-first century vision and action. In $W$ orld Conference on Higher Education: UNESCO Paris 5-9 October 1998. Volume 1, final report. Available online at http://unesdoc.unesco.org/images/0011/001163/116345e.pdf

27. Sun, P.; Tsai, R.J.; Finger, G.; Chen, Y.; Yeh, D. (2008). What drives a successful e-Learning? An empirical investigation of the critical factors influencing learner satisfaction. In Computers and Education, 50(4), (pp. 1183-1202). doi:10.1016/j.compedu.2006.11.007. 
28. The White House (2014). Higher education. Available online at http://www.whitehouse.gov/issues/education/higher-education

29. Williams, B. (2013). Roll call: taking a census of MOOC students. In Proceedings of the 1 st Workshop on Massive Open Online Courses at the 16th Annual Conference on Artificial Intelligence in Education. Memphis, TN. Paper Available online at http://people.csail.mit.edu/zp/moocshop2013/paper_18.pdf

30. Willging, P.A. and Johnson, S.D. (2009). Factors that influence students' decision to dropout of online courses. In Journal of Asynchronous Learning Networks, 13(3), (pp. 115-127).

31. Yuan, L. and Powell, S. (2013). MOOCS and open education: Implications for higher education. A white paper. (Jisc CETIS 2013:WP01). Available online at http://publications.cetis.ac.uk/2013/667

\section{Acknowledgements}

I would like to thank the UK Higher Education Academy National Teaching Fellowship Scheme for funding this research. Particular thanks go to Anne Robertson and Claire Leschi who provided the French translation of the abstract. 


\section{Annex 1}

\section{References included in the analysis}

1. Adams, C.; Yin, Y.; Madriz, L.F.V. and Mullen, S.C. (2014). A phenomenology of learning large: the tutorial sphere of xMOOC video lectures. In Distance Education, 35(2), (pp. 202-216). doi:10.1080/01587919.2014.917701.

2. Ahn, J.; Butler, B.S.; Alam, A. and Webster, S.A. (2013). Learner participation and engagement in open online courses: insights from the Peer 2 Peer university. In MERLOT Journal of Online Learning and Teaching, 9(2), (pp. 160-171).

3. Aiken, J.M.; Lin, S.Y.; Schatz, M.F. and Caballero, M.D. (2013). The initial state of students taking an introductory physics MOOC. arXiv preprint arXiv:1307.2533.

4. Andersen, R. and Ponti, M. (2014). Participatory pedagogy in an open educational course: challenges and opportunities. In Distance Education, 35(2), (pp. 1-16). doi:10.1080/01587919.2014.917703.

5. Balakrishnan, G. (2013). Predicting student retention in massive open online courses using bidden Markov models. Available online at http://www.eecs.berkeley.edu/Pubs/TechRpts/2013/EECS-2013109.pdf

6. Beaven, T.; Hauck, M.; Comas-Quinn, A.; Lewis, T.; de los Arcos, B. (2014). MOOCs: Striking the right balance between facilitation and self-determination. In MERLOT Journal of Online Learning and Teaching, 10(1), (pp. 31-43).

7. Chen, Z.; Cheng, J.; Chia, D. and Koh, P. W. (2012). CS224W Final report engagement, interaction, and retention in online classes. Available online at http://web.stanford.edu/class/cs224w/projects.html

8. Clow, D. (2013). MOOCs and the funnel of participation. In D. Suthers, K. Verbert, E. Duval \& X. Ochoa (eds.), $L A K ' 13$ Proceedings of the Third International Conference on Learning Analytics and Knowledge, (pp. 185-189). Belgium, 8-12 April 2013.

9. DeBoer, J.; Stump, G.S.; Seaton, D. and Breslow, L. (2013). Diversity in MOOC students' backgrounds and behaviors in relationship to performance in $6.002 \mathrm{x}$. In the Proceedings of the Sixth Learning International Networks Consortium Conference, Cambridge, Massachusetts, 16-19 June 2013.

10. DeBoer, J.; Ho, A.D.; Stump, G.S. and Breslow, L. (2014). Changing “course": Reconceptualizing educational variables for massive open online courses. In Educational Researcher, 43(2), (pp. 74-84). doi: 10.3102/0013189X14523038.

11. DeWaard, I.; Abajian, S.; Gallaghe, M.S.; Hogue, R.; Keskin, N.; Koutropoulos, A.; Rodriguez, O.C. (2011). Using mLearning and MOOCs to understand chaos, emergence, and complexity in education. In The International Review of Research in Open and Distance Learning, 12(7). Available online at http://www.irrodl.org/index.php/irrodl/article/view/1046/2026

12. Emanuel, E.J. (2013). MOOCs taken by educated few. In Nature, 503, (pp. 342). doi:10.1038/503342a.

13. European Commission [EC] (2014). Report on web skills survey. Support services to foster Web Talent in Europe by encouraging the use of MOOCs focused on web talent. (European Commission D1.1 First Interim Report). Available online at http://openeducationeuropa.eu/sites/default/files/MOOCs-for-web-skills-survey-report.pdf 
14. Fini, A. (2009). The technological dimension of a massive open online course: The case of the CCK08 course tools. In International Review of Research in Open and Distance Learning, 10(5). Available online at http://www.irrodl.org/index.php/irrodl/article/view/643/1402

15. Forsey, M.; Low, M. and Glance, D. (2013). Flipping the sociology classroom: Towards a practice of online pedagogy. In Journal of Sociology, 49, (pp. 471). doi: $10.1177 / 1440783313504059$

16. Gillani, N. (2013). Learner communications in massively open online courses. Oxford Centre for Higher Education Policy Studies. Available online at http://oxcheps.new.ox.ac.uk/MainSite\%20pages/Resources/OxCHEPS_OP53.pdf

17. Gooding, I.; Klaas, B.; Yager, J.D.; Kanchanaraksa, S. (2013). Massive open online courses in public health. In Frontiers in Public Health, 1(59). doi: 10.3389/fpubh.2013.00059.

18. Griesbaum, J. (2014). Students as teachers in MOOCs? The double gain of MOOCs as an inclass teaching method experiences from a student-made MOOC "Online Data Privacy". In International Journal of Information and Education Technology, 4(1), (pp. 29-34). doi: 10.7763/IJIET.2014.V4.363.

19. Grunewald, F.; Meinel, C.; Totschnig, M. and Willems, C. (2013). Designing MOOCs for the support of multiple learning styles. In D. Hernandez-Leo, T. Ley, R. Klamma \& A. Harrer (eds.), 8th European Conference, on Technology Enhanced Learning, (pp. 371-382). EC-TEL 2013, Paphos, Cyprus. September 17-21. Available online at http://www.hpi.unipotsdam.de/fileadmin/hpi/FG_ITS/papers/WebUniversity/2013_Gruenewald_ECTEL.pdf

20. Guo, P.J. and Reinecke, K. (2014). Demographic differences in how students navigate through MOOCs. In Proceedings of the first ACM conference on Learning@ scale conference, Vancouver, BC, March 14-55. Available online at https://groups.csail.mit.edu/uid/otherpubs/las2014-pguo-demographic.pdf

21. Irvine, V.; Code, J. and Richards, L. (2013). Realigning higher education for the 21st-century learner through multi-access learning. In MERLOT Journal of Online Learning and Teaching, 9(2), (pp. 172-186).

22. Khalil, H. and Ebner, M. (2013). "How satisfied are you with your MOOC?" - A Research Study on Interaction in Huge Online Courses. In J. Herrington, A. Couros, \& V. Irvine (eds.), Proceedings of $W$ orld Conference on Educational Multimedia, Hypermedia and Telecommunications, Victoria, Canada, June 24 2013. ISBN 978-1-939797-03-2.

23. Kop, R. (2011). The challenges to connectivist learning on open online networks: Learning experiences during a massive open online course. In The International Review of Research in Open and Distance Learning, 12(3), (pp. 19-38). Available online at http://www.irrodl.org/index.php/irrodl/article/view/882/1689

24. Kop, R. and Carroll, F. (2012). Cloud Computing and Creativity: Learning on a Massive Open Online Course. In European Journal of Open, Distance and e-Learning, (Special Issue: Best of EDEN 2011). Available online at http: / $/$ www.eurodl.org $/$ index.php?p $=$ special\&sp $=$ articles\&inum $=4 \&$ article $=542$

25. Kop, R.; Fournier, H. and Mak, J.S.F. (2011). A pedagogy of abundance or a pedagogy to support human beings? Participant support on massive open online courses. In The International Review of Research in Open and Distance Learning, 12(7), (pp. 74-93). Available online at http://www.irrodl.org/index.php/irrodl/article/view/1041/2025

26. Koutropoulos, A.; Gallagher, M.S.; Abajian, S.C.; DeWaard, I.; Hoque, R.J.; Keskin, N.O.; Rodriquez, C.O. (2012). Emotive vocabulary in MOOCs: Context \& participant retention. In 
European Journal of Open, Distance and e-Learning, 2012/II. Available online at http:/ www.eurodl.org $/ \mathrm{p}=$ archives\&year $=2012 \&$ halfyear $=1 \&$ article $=507$

27. Kulkarni, C.; Wei, K.P.; Le, H.; Chia, D.; Papadopoulos, K.; Cheng, J.; Klemmer, S.R. (2013). Peer and self assessment in massive online classes. In ACM Transactions on Computer-Human Interaction (TOCHI), 20(6), (pp. 33). doi: 10.1145/2505057.

28. Levy, D. (2011). Lessons learned from participating in a connectivist massive online open course (MOOC). In Y. Eshet-Alkalai, A. Caspi, S. Eden, N. Geri \& Y. Yair (eds.), Proceedings of the Chais conference on instructional technologies research: Learning in the technological era, (pp. 31-36). Available online at http://www.openu.ac.il/research_center/chais2011/download/f-levyd94_eng.pdf

29. Li, N.; Verma, H.; Skevi, A.; Zufferey, G.; Blom, J.; Dillenbourg, P. (2014). Watching MOOCs together: investigating co-located MOOC study groups. In Distance Education, 35(2), (pp. 217-233). doi:10.1080/01587919.2014.917708

30. Liyanagunawardena, T.; Adams, A.; Rassool, N. and Williams, S. (2013c). Using non-personal computers for eLearning: Sri Lankan experience. In Journal of Education and Training Studies, 1(2), (pp. 152-158). Available online at http://redfame.com/journal/index.php/jets/article/view/96/135

31. Mackness, J.; Mak, S.F.J. and Williams, R. (2010). The ideals and reality of participating in a MOOC. In L. Dirckinck-Holmfeld, V. Hodgson, C. Jones, M. De Laat, D. McConnell \& T. Ryberg (eds.), Proceedings of the 7th International Conference on Networked Learning, (pp. 266-274). Denmark, 3-4 May 2010. Available online at http://www.lancaster.ac.uk/fss/organisations/netlc/past/nlc2010/abstracts/PDFs/Mackne ss.pdf

32. Mackness, J.; Waite, M.; Roberts, G. and Lovegrove, E. (2013). Learning in a small, taskoriented, connectivist MOOC: Pedagogical issues and implications for higher education. In The International Review of Research in Open and Distance Learning, 14(4). Available online at: http://www.irrodl.org/index.php/irrodl/article/view/1548/2636

33. Mak, S.F.J., Williams, R. and Mackness, J. (2010). Blogs and forums as communication and learning tools in a MOOC. In L. Dirckinck-Holmfeld, V. Hodgson, C. Jones, M. De Laat, D. McConnell \& T. Ryberg (eds.), Proceedings of the 7th International Conference on Networked Learning, (pp. 275-284). Denmark, 3-4 May 2010. Available online at

http://eprints.port.ac.uk/5606/1/Blogs_and_Forums_as_Communication_Tools_in_a_MO OC.pdf

34. Milligan, C.; Littlejohn, A. and Margaryan, A. (2013). Patterns of engagement in connectivist MOOCs. In MERLOT Journal of Online Learning and Teaching, 9(2), (pp. 149-159).

35. Paton, C. (2014). Massive open online course for health informatics education. In Healthcare informatics research, 20(2), (pp. 81-87). doi: 10.4258/hir.2014.20.2.81.

36. Rodriguez, C.O. (2012). MOOCs and the AI-Stanford like courses: Two successful and distinct course formats for massive open online courses. In European Journal of Open and Distance Learning, 2012/II. Available online at http:/ /www.eurodl.org/index.php?p=archives\&year $=2012$ \&halfyear $=2 \&$ article $=516$

37. Root, K.M.V. (2014). Canine theriogenology for dog enthusiasts: Teaching methodology and outcomes in a massive open online course (MOOC). In Journal of Veterinary Medical Education, 41(1), (pp. 9-18). doi: 10.3138/jvme.0813-112R1. 
38. Rose, C.P.; Carlson, R.; Yang, D.; Wen, M.; Resnick, L.; Goldman, P.; Sherer, J. (2014). Social Factors that Contribute to Attrition in MOOCs. In the Proceedings of the first ACM conference on Learning@ scale conference, (pp197-198). March 4-5, USA. doi:10.1145/2556325.2567879.

39. Saadatmand, M. and Kumpulainen, K. (2014). Participants' Perceptions of Learning and Networking in Connectivist MOOCs. In MERLOT Journal of Online Learning and Teaching, 10(1), (pp. 16-30).

40. Seaton, D.T.; Bergner, Y.; Chuang, I.; Mitros, P.; Pritchard, D.E. (2013). Towards real-time analytics in MOOCs. In Proceeding of: 3rd International Conference on Learning Analytics and Knowledge. 8-12 April 2013. Available online at http://ceur-ws.org/Vol-985/paper3.pdf

41. Spoelstra, H.; van Rosmalen, P. and Sloep, P. (2014). Toward project-based learning and team formation in open learning environments. In Journal of Universal Computer Science, 20(1), (pp. 57-76). Available online at

http://www.jucs.org/jucs_20_1/toward_project_based_learning/jucs_20_01_0057_0076_sp oelstra.pdf

42. Stewart, B. (2010). Social media literacies and perceptions of value in open online courses. Available online at http://portfolio.cribchronicles.com/wp-

content/uploads/2012/11/612701_Social_Media_Literacies_MOOCs.pdf

43. Vazquez-Cano, E. (2013). The videoarticle: New reporting format in scientific journals and its integration in MOOCs. In Comunicar, 21(41), (pp. 83-91). Available online at http:/ / hdl.handle.net/10760/19781 